\title{
Effectiveness of Life Skill Training towards Improvement of Self-Business of Society
}

\begin{abstract}
Abd. Hamid Isa
Abstract

Life skill education training is an important program as it can provide opportunity for society to develop their potency. Then, urgency of society empowerment as target of non-formal education effort is expected to be able to provide development space for productive business of society as alternative of solving encountered problems and it is implementation of self-business of coastal society and or fisherman society.

Problem statement of this research is whether or not an effective life skill training can improve coastal society self-business. This research aims to (1) investigate objective condition of life skill education in coastal society environment, (2) investigate implementation of life skill training in improving self-business of coastal society, and (3) investigate effectiveness of life skill training in improving self-business of coastal society.

This is a research and development type which means that it is a strategy to improve quality of education and answer particular questions on practical issues through 'applied research' which is used in improving educational practices. The research is located in Village of Bongo, Sub-district of Batudaa Pantai, District of Gorontalo, Gorontalo Province and the subject is 30 people. Data of the research are collected through observation, documentation study and interview. Assessment activity is conducted by doing pretest and posttest and it is continued by comparing them entirely with participants' work in the field. The data are analyzed qualitatively which is supported by quantitative data. Thus, measuring result of pre-test and post-test is also with both qualitative and quantitative analysis.

Research findings reveal that (1) objective condition of life skill education for in coastal society environment is not yet planned based on educational format which applies model and stages in the implementation of education and training, (2) appropriateness of implementation of life skill training is commonly tested through techniques of: model quality analysis, expert assessment and field testing, and (3) the developed life skill training based on both qualitative and quantitative analysis is effective in improving self-business of society.

Result of analysis reveals that life skill training containing four indicators namely personal, social, academic and vocational skill give observed influence in form of improvement of self-business of coastal society.
\end{abstract}

Keywords: $\quad$ Life Skill Training, Self-Business

\section{INTRODUCTION}

Life skills is a concept that often discussed by scholars and organisations, especially those in health and education. Life skills concept in health, as defined by WHO is a skill or human ability to adapt and to behave positively, which enable individual to overcame various challenges in life effectively, especially in health and welfare aspects.

The importance of life skills education for individual is mostly because individual faced various problems in life. And that these life skills are needed by individuals to become independent individual, community members, and citizens. Hence, through these life skills mastery, individuals are expected to be able to solve problems and find alternative solutions, that have positive implications on him/herself or others. These behaviours and characters are what made them able to adapt and survive amidst the life challenges, and empower them to contribute for their nations.

In other dimension, the effort to empower community is also influenced by level of lives and geographical factors especially for the coastal community. These conditions influenced their livelihood and their independence in doing business for the local fishermen. The area that closely located to the sea has made its population mostly live as fishermen. For those who live near the bay, their livelihood are mostly fishermen, seaweed farmers, and also fish and crabs' farmers, as well as processing other sea products.

Community's independence in doing business is closely related to social environmental system, cultural system, and socio-economic changes, which also influence the community's interaction itself. Transformation of various cultural values within the society have to be regarded in efforts to prepare human resources through education, training, and potentials' development, and community 
empowerment that are expected by individuals, community and the nation.

Studies on implementation of life skills trainings for community is important to be done as it prepares them to be able to fulfil their needs in life, thus the community will be able to work and do business individually or collectively. In addition it can also empower and motivate them to work independently, which in turn will have impact on the increase of their income and the increase of their life quality.

This study is based on the problems whether or not life skills training is effective in increasing the coastal community's independence in doing business. Therefore, this study is aimed at (1) finding out the objective condition of life skills education within the coastal community, (2) finding out the implementation of life skill training in increasing the coastal community's independence in doing business, and (3) finding out the effectiveness of life skills training in increasing the coastal community's independence in doing business.

This study is based on several grand theories such as, non-formal education, training, life skills and independence in doing business.

1. Non-formal education

Non-formal education according to Coombs in Sudjana (2001:22) is each organized and systematic educational activity outside the formal school system, which independently implemented or is an important part of wider activity, which is purposefully implemented to serve certain learners to achieve the learning objectives.

Hamijoyo (in Kamil 2010: 32) defines nonformal education as ... a systematically and continuously organized education outside the formal school system through social relationship process to guide individual, groups, and community to have positive and constructive social attitude to improve their welfare, social intelligent of the nation and friendship and peace among mankind.

Napitupulu in Sihombing (1999: 49) defines non-formal education as each educational service provided outside the school system which last longlife, purposefully implemented, systematically, and well planned to actuate human potentials (attitude, actions, and works) to create eager to learn human being to increase their welfare level.

Non-formal education as educational activity is implemented outside formal school system either institutionalized or not through learning activities that does not necessarily multi layers but sustainable.
Yoesef dan Santosa (1987: 19) stated that nonformal education is each opportunity where there is a regular communication outside the school and people gain information, knowledge and training, that suit the age and the needs, in order to enable them to effectively and efficiently participate in their community and the nation.

Based on the above description it can be concluded that non-formal education is an educational service activity toward the community which implemented outside the formal school system to actualize their knowledge, attitude, and skill potentials that needed to develop productive and qualified human being.

\section{Training}

Edwin B. Plippo (in Kamil, 2010: 3) stated, "training is the act of increasing the knowledge and skill of an employee for doing a particular job". Further, Michael J. Jucius (1972) added, "the term training is used here to indicate any process by which the aptitudes, skills, and abilities of employees to perform specific jobs are increased". From these statements, it is clear that training activity is often viewed in relation to certain jobs, however, in reality, trainings do not necessarily related to jobs or does not necessarily intended for employees.

Simamora (1997: 287) defines training as series of activities designed to increase skills, knowledge, experience, or changes in individuals. Kenneth R. Robinson (in Rifaid, 2000: 12) mentioned, "training therefore we are seeking by any instruction behaviour pattern in the area of knowledge, skill or attitude in order to achieve a desired standard". Training is a learning process which happened in certain space or in the field. Further, Max Foster (1979) in Rifaid (2000:3) explained: "that training should create conditions and stimuli to accomplish four things: (1) to evoke responses in others; (2) to develop knowledge, skills, and attitudes, (3) to produce changes in behaviour, and (4) to attain specific objectives."

This statement by Max Foster indicates that training has to create conditions and supports to improve four things that is to evoke responses in others, to produce changes in behaviour and to attain specific behaviour. In this sense, through training activity, that changes to eliminate discrepancy between the present and the expected future happens.

\section{Life skills}

Life skills are often discussed by experts and authoritative institutions in education and health sector such as, Brolling (1989) which stated that life 
skills is interaction among many knowledge and skills, which are important for individuals to have in order to live Independently.

According to Kent Davis (2000:1) life skills is "personal manual" for one's body. These life skills help learners to learn how to maintain herself, grows up to be himself/herself, work appropriately with others, make logical decisions, protect himself/herself and attain their objectives in life.

Life skills means more than just skills for work. People who work in domestic area, such as housewife, retired people, or children also in need of life skills. As for working people, they face many challenges. Even for those who are currently studying, they also need life skills because they have their own problems.

Life skills consists of four types: first, personal skills which consisted of self awareness and rational thinking skills; second, social skills; third, academic skills, and fourth, vocational skills.

\section{Independence in doing business}

Independence is something that can be earned or improved. As Kamil (2002: 91) mentioned that independence values owned by individuals would only be perfect when it is supported by independence attitude such as: psychosocial independence, cultural and economic independence, discipline, initiative and entrepreneurship, leadership and orientation to excel in competition. Independence as a personality or mental attitude has to be owned by every individual, because within independence, there were elements of personality that can be developed in order to make it ingrained in our lives. Within the context of non-formal education, independence is the baseline in each program development in each program development. Non-formal education curriculum, specifically have core which refers to grow and develop independence values for each target learners.

On the perspective of community development, according to UN (1956) in Kamil (2002: 93) independence is: The participation of the people themselves in efforts to improve their level of living with as much relieve in way which encourage initiative, self-help and mutual help and make these more effective.

\section{METHODS}

This study implements research and development method to develop and validate the result of the non-formal education and to find new knowledge through basic research. This study is also intended to answer specific questions on practical problems through applied research which is used to increase educational practices. This study consisted of two activities: (1) exploration, that is qualitative, and (2) experimentation. The first activity is conducted explorative-qualitatively. The second activity is conducted through try out by using preexperiment method. This study is conducted in Bongo village of Batudaa pantai sub-district, Gorontalo district, and the target is 30 productive community members.

In this study, the data collection methods are: (1) observation, (2) document study, and (3) interview. Data are analysed qualitatively supported by quantitative data, the pre-test and post-test result are analysed qualitatively and quantitatively.

\section{RESEARCH FINDINGS}

1. Findings on life skills training to increase independence in doing business based on objective conditions are: (1) program designed for fishermen community have not fully oriented on needs analysis and strategic plan for the program implemented, (2) program implementation does not follow proper management principles, hence, the process and the result is not as expected, (3) implementation of trainings do not involve pre-test for trainees, therefore, these activities are conducted without analysis on the trainees' needs, (4) the objective of the training is not explicitly formulated to develop independence of doing business for the trainees, (5) training programs material are developed without systematic and proper planning to suit the training principles, (6) resource person and facilitator in the activity do not explain what competencies are expected to be mastered at the end of the training program, thus, the training activity does not encourage and stimulate the trainees enthusiasm, (8) training activity was less conducive because the approach is not based on adult learning and participatory approach, (9) limitation of training and practice facilities and infrastructure has made the training unable to develop the intended life skills, and (10) evaluation is not well planned and integrated into other components, hence, the baseline data for the assessment criteria of training is not clear.

2. The findings show that in life skills training to increase independence on doing business, the implementation is always preceded by 
identification of participants' needs, fullowed by planning, training process, and output and outcome. This model is different with the current model that usually implemented in top down manner, without prior identification and summed up with assessment or ended with output without any further development or impact of the implemented program. In addition, the current operational of the training programs only limited on cognitive aspects, and still not touching the motoric aspects. This model of program is less effective because it has not given comprehensive solution toward the subjects' problem. This study on the life skills training for independence in doing business offers an alternative model in empowering the coastal community. Thus, this model is not only teaching knowledge and skills, but also development of skills to help facilitate the community to work and do their business as well as become productive workers who have entrepreneurship knowledge, which eventually will establish independence on doing business.

3. The qualitative and quantitative analysis on this research findings show that training's participants are empowered through training activity to make them independence in doing their business. The findings and qualitative analysis are supported by the quantitative findings. The quantitative analysis show that there is a significant difference between knowledge and participants' skill before and after their participation in the training, hence, it can be said that life skill training is effective in empowering the participants to have knowledge and skills in doing business. In addition, the analysis also revealed that there is an increase in the independence on doing business for coastal community as the impact of this administration of life skill training. Implementation of this type of training consists of four life skills indicators namely, personal skill, social skill, academic skill, and vocational skills, in which those skill give impact that can be observed through the increase of coastal community's independence in doing business.

The analysis also shows in sequence indicators that contributed to the effectiveness of independence in doing business are: (1) academic skills by $13.764 \%$, (2) social skill by $10.112 \%$, (3) vocational independence by
$7.182 \%$, and (4) personal skill by $6.503 \%$. Therefore, it can be concluded that simultaneously, personal skill, social skill, academic skill, and vocational skill contribute toward the independence of coastal community in doing business by $16.484 \%$.

\section{CONCLUSIONS}

1. Objective condition of life skill education in coastal community based on the data and analysis of the preliminary study conducted in form of socialization and assistance toward fishermen community by the Marine and Fisheries Agency of Gorontalo province. The life skills education program for coastal community had not been designed to suit the education program which should implement model and processes as usually found in education and training programs.

2. Implementation of life skills training based on the analysis showed that in general development of life skill education model has been tested its appropriateness through: model quality analysis, expert validation, and field try out. The analysis on the quality of the model, which was systematically tested on its content, relevancy, and principles of the model development, concludes that the life skill education model can increase the independence of coastal community in doing business and that this model has create appropriate relationship among the components of the model.

3. Life skill training developed in this study has been prove effective in increasing the coastal community's independence in doing business. The training activity consists of four indicators of personal skill, social, academic skills, and vocational skills which influence the increase of coastal community's independence in doing business. 


\section{REFERENCES}

[1] Ahmed, M dan Coombs, P.H. (1977). Education for Rural Development: Case Studies for Planners. New York : Prager Publishers.

[2] Ahmed, M, (1975), The Economics of Non Formal Education (Resources, Cost and Beneft), New York, Praeger Publishers.

[3] Anwar. (2003).Pengembangan Model Pengelolaan Pembelajaran Keterampilan Berbasis Sosial Budaya Bagi Perempuan Nelayan. Disertasi Program Pascasarjana UPI: Tidak diterbitkan.

[4] ............ (2004). Pendidikan Kecakapan Hidup (Life Skills).Bandung: Alfabeta

[5] Borg W.R and Gall, M.D (1989). Education Research An Introduction. New York: Pinancing. Washington; the Word Bank

[12]

[13] Sihombing. U.(1999). Pendidikan Luar Sekolah Kini dan Masa Depan Jakarta:PD Mahkota.

[14] --andikan Luar Sekolah Manajemen Strategi Jakarta : PD Mahkota.

[15] Simamora, H. (1997). Manajemen Sumber Daya Manusia.Jakarta: STIE.YPKN.

[16] Sudjana. (2001).Manajemen Program Pendidikan; untuk Pendidikan Luar Sekolah dan Pengembangan Sumber Daya Manusia Bandung: Falah Production.
[6] Borg W.R \& Biklen (1989).Education Research. New York: Pitman Publishing.

[7] Coombs, P dan Manzoor A. (1984).Memerangi Kemiskinan di Pedesaan Melalui Pendidikan Nonformal.Jakarta : Rajawali

[8] Joesoef, Soelaiman.Slamet Santoso (1987). Konsep Dasar Pendidikan Luar Sekolah.Surabaya. Bumi Aksara.

[9] Kamil, Mustofa.(2002). Model Pembelajaran Magang Bagi Peningkatan Kemandirian Warga Belajar. Disertasi Program Pascasarjana UPI: Tidak diterbitkan.

[10] --angembangkan Pendidikan Nonformal Melalui PKBM di Indonesia. Sebuah Pembelajaran dari Kominkan di Jepang. University of Tsukuba.

[11] Rifaid. (2000). Dampak Pelatihan Keterampilan Terhadap Perubahan Sikap dan Perilaku serta Kemandirian Bekas Wanita Tuna Susila (WTS)di Nusa Tenggara Barat. Tesis Program Pascasarjana UPI. Tidak diterbitkan. 